\title{
i-Tree Eco Analysis of Landscape Vegetation on Remediated Areas of Oak Ridge National Laboratory
}

\author{
Sally Ross ${ }^{1}$, Sharon Jean-Philippe ${ }^{2}$, Wayne Clatterbuck ${ }^{2}$, Neil Giffen ${ }^{3}$, Jamie Herold ${ }^{3}$, John Zobel ${ }^{4}$ \\ ${ }^{1}$ School of Environment and Natural Resources, The Ohio State University, Columbus, OH, USA \\ ${ }^{2}$ Department of Forestry, Wildlife and Fisheries, University of Tennessee, Knoxville, USA \\ ${ }^{3}$ Oak Ridge National Laboratory, Oak Ridge, TN, USA \\ ${ }^{4}$ University of Minnesota, Saint Paul, MN, USA \\ Email: ross.1668@osu.edu, jeanphil@utk.edu, wclatter@utk.edu,giffennr1@ornl.gov, heroldjm@ornl.gov, jzobel@umn.edu
}

How to cite this paper: Ross, S., JeanPhilippe, S., Clatterbuck, W., Giffen, N., Herold, J., \& Zobel, J. (2020). i-Tree Eco Analysis of Landscape Vegetation on Remediated Areas of Oak Ridge National Laboratory. Open Journal of Forestry, 10, 412427.

https://doi.org/10.4236/ojf.2020.104026

Received: March 28, 2020

Accepted: October 8, 2020

Published: October 11, 2020

Copyright $(\odot 2020$ by author(s) and Scientific Research Publishing Inc. This work is licensed under the Creative Commons Attribution International License (CC BY 4.0).

http://creativecommons.org/licenses/by/4.0/

\begin{abstract}
The Oak Ridge National Laboratory (ORNL) is the largest and most diverse energy, research, and development institution within the Department of Energy (DOE) system in the United States. As such, the site endures constant land development that creates rigorous growing conditions for urban vegetation. Natural resource managers at ORNL recognize that trees are an integral component of the landscape and are interested in characterizing the urban forest and their associated ecosystem services benefits. We evaluated the urban forest structure, quantified ecosystem services and benefits, and estimated economic value of resources using $\mathrm{i}$-Tree Eco at ORNL. While this assessment captured over 1100 landscape trees, the ORNL Natural Resources Management for landscape vegetation can be expanded to include unmanaged landscapes, e.g. riparian areas, greenspace, and other vegetative attributes to increase ecosystem services benefits. Assigning a monetary value to urban forest benefits help to inform decisions about urban forest management, ideally on cost-benefit analysis.
\end{abstract}

\section{Keywords}

Urban Tree(s), Urban Forest, Urban Vegetation, Landscape Vegetation, Tree Inventory, Tree Assessment, Ecosystem Service(s), Ecological Function, i-Tree Eco, Economic Valuation

\section{Introduction}

The importance of ecosystem services (ES) is increasingly taking center stage in 
the development of more sustainable and resilient cities. Several studies have modeled how ES is evaluated within cities, such as conservation assessment (Egoh et al., 2007; McDonald et al., 2013), capital assets (Liu et al., 2010), and policymaking indicators (Layke et al., 2012). Ecosystem service(s) represent(s) complex and diverse concepts, with broad and often conflicting definitions among conservation organizations (Nahlik et al., 2012). Such contradictions have inhibited the development of concise operational definitions and methods of measurements, as well as coherent and comprehensive conservation policy objectives and goals among natural resources regulatory organizations (Perrings et al., 2010, 2011; Reyers et al., 2012). For example, in the Millennium Ecosystem Assessment, the concept of ES was developed to represent the diversity of benefits provided by ecological subsystems for human well-being (Millennium Ecosystem Assessment, 2005). However, there are tangible environmental services (i.e. carbon dioxide sequestration, particulate matter mitigation, cooling effects) that are easily estimated and monetized using approved methodologies (Small et al., 2017), while cultural services (i.e. human perceptions and values), which are non-material ecosystem services, cannot be easily measured but are imperative in the evaluation of ES (Jennings et al., 2016).

Ecosystem services are defined as the benefits human populations derive, either directly or indirectly, from ecosystem functions (Costanza et al., 2014). Ecosystem services are typically grouped into four categories: provisioning, regulating, supporting, and cultural services (Millennium Ecosystem Assessment, 2005). Specifically, in urban areas these services direct maintenance processes supporting (physical, chemical, and biological), provisioning (wood, fiber, air, water), regulating (stormwater mitigation), and influencing cultural services (recreational and tourism) (Millennium Ecosystem Assessment, 2005; Weber, 2012). Ecosystem services generated by urban ecosystems have crucial importance for the quality of life and public health for urban residents. Green infrastructure in urban environments, specifically trees, provides essential benefits and services that promote sustainability, provide human comfort, and help alleviate environmental problems.

Studies have found that urban trees that attain heights $\sim 15 \mathrm{~m}(49 \mathrm{ft})$ or larger, benefit the urban environment by absorbing significant amounts of atmospheric pollutants, sequestering carbon, reducing urban heat island (UHI), and stormwater runoff impacts (Andrew \& Slater, 2014). Air pollution is a persistent environmental problem in most major cities around the world and research efforts have focused on how vegetation can assist in mitigating these pollutants (Ning et al., 2016). Historically, Urban Forest Effect (UFORE) Models have been used to calculate tree benefit estimates for carbon storage (C) in urban trees (Nowak, 1993; Jo \& McPherson, 1995). A study by Nowak (1993) estimated C storage of urban trees in Oakland; CA ranged between 350 and 750 million tonnes. In a follow-up study in Chicago, IL, Nowak (1994) found that urban trees stored between 600 and 900 million tonnes of carbon. Nowak et al. (2002) conducted an eight-city study on C storage and national urban tree cover data. The study con- 
cluded that greater $\mathrm{C}$ amounts were stored or sequestered in cities that had increased urban tree canopy cover, and mature healthy trees. Additionally, urban trees can help to reduce global temperature fluxes by indirectly mitigating the consumption of fossil fuels from heating and cooling (Kuchelmeister, 1997). The UHI effect is defined as increased air and surface temperatures in urban areas compared to surrounding suburban and exurban areas (Solecki et al., 2005). Researchers have studied several potential migration strategies to reduce UHI effects in cities (Solecki et al., 2005; Rosenfeld et al., 1998) such as incorporating building material that reduces heat absorption and increases canopy cover. Urban trees and shrubs are essential in reducing stormwater runoff volumes and discharge from impervious urban catchments because they intercept precipitation, while their root systems can filtrate sediments/pollutants to help to recharge aquifers in urban areas and reduced urban flooding (EPA, 2013). A 2013 study of New York City's urban forest found that the urban trees provide 4.6 million dollars in stormwater benefit savings and helped to reduce runoff by an estimated 69 million cubic feet annually (USDA Forest Service, 2019). The above-mentioned studies demonstrate the necessity to continue research efforts that include multi-scale studies that assess urban landscapes, inventory tree resources, and ecosystem services functions.

\section{Efforts to Promote Urban Forestry at Oak Ridge National Laboratory}

The Oak Ridge National Laboratory (ORNL) is an active federal research facility that includes contaminated areas and structures used during the Manhat$\tan$ Project (1942-1948) to present. Originally used for the production and separation of plutonium during World War II, significant amounts of chemical waste were deposited into the soil, buried, and directly discharged into local waterways (Jean-Philippe, 2010). The US Department of Energy and Environmental Protection Agency (EPA) is dedicated to the cleanup of the Bethel Valley facilities, which include remediating contaminated soils, sediments, water, and infrastructure (UCOR DOE OREMP, 2019). Across the ORNL campus, the decommissioning and demolition of many of the facilities has led to the presence of brownfields and greyfields. ORNL seeks to enhance the campus environmental experience and increase its overall campus sustainability, by developing and maximizing the benefits of the urban forest. Over the past seven decades, the activities at ORNL have shifted and policymakers have worked to make ORNL environmentally sustainable through effective and strategic planning. To guide the future of environmental resources and sustainable landscape practices on ORNL's campus stakeholders have developed the "Sustainable Landscape Initiative Plan 2020 ". One of the objectives of the Sustainable Landscape Initiative 2020 was to inventory and assess the vegetation present on the ORNL campus and quantify the ecosystem services associated with the vegetation.

The environmental problems affecting ORNL resemble those impacting urban communities worldwide (i.e. fragmentation, habitat destruction, and increased grey infrastructure). These environmental problems interfered with ORNL's mission to develop a sustainable and resilient campus. The objective of this paper 
was to assess urban trees across the ORNL campus. Specifically, we evaluated the urban forest structure, quantified ecosystem services and benefits, and estimated the economic value of resources using i-Tree Eco model. We further determined which tree characteristics (i.e. leaf area, dbh) were most important in predicting environmental effects that increased ecosystem service benefits using i-Tree Eco model.

\section{Methods}

\section{Site Description}

The Oak Ridge National Laboratory is located on the Oak Ridge Reservation (ORR) in Anderson and Roane County Tennessee, USA (Figure 1, 2018-ASER). The ORR is located in the temperate region and has four distinct seasons. The average low temperature is $8.4^{\circ} \mathrm{C}$, the average high temperature is $20.8^{\circ} \mathrm{C}$, and annual precipitation is $139.9 \mathrm{~cm}$ (Data United States Climate, 2018). According to the Anderson Soil Survey (USDA, 1981), the general soil types found in the Bethel Valley were generally classified as either Colbert Series or Upshur Series silty clay loams. The dominant forest cover type on the ORR is oak-hickory, mixed forest, and conifer (Parr et al., 2015). The ORNL site occupies approximately 1808.9 ha (4470 acres) and includes facilities in two valleys-Bethel Valley and Melton Valley (Figure 1). Bethel Valley is the site of the main campus area which has over 190 buildings and over 4500 daily occupants. The site has many different land uses including research laboratories, brownfields, greyfields, undeveloped areas, and natural areas. The ORNL main campus where this tree inventory was conducted constitutes approximately 190.2 ha (469 acres).

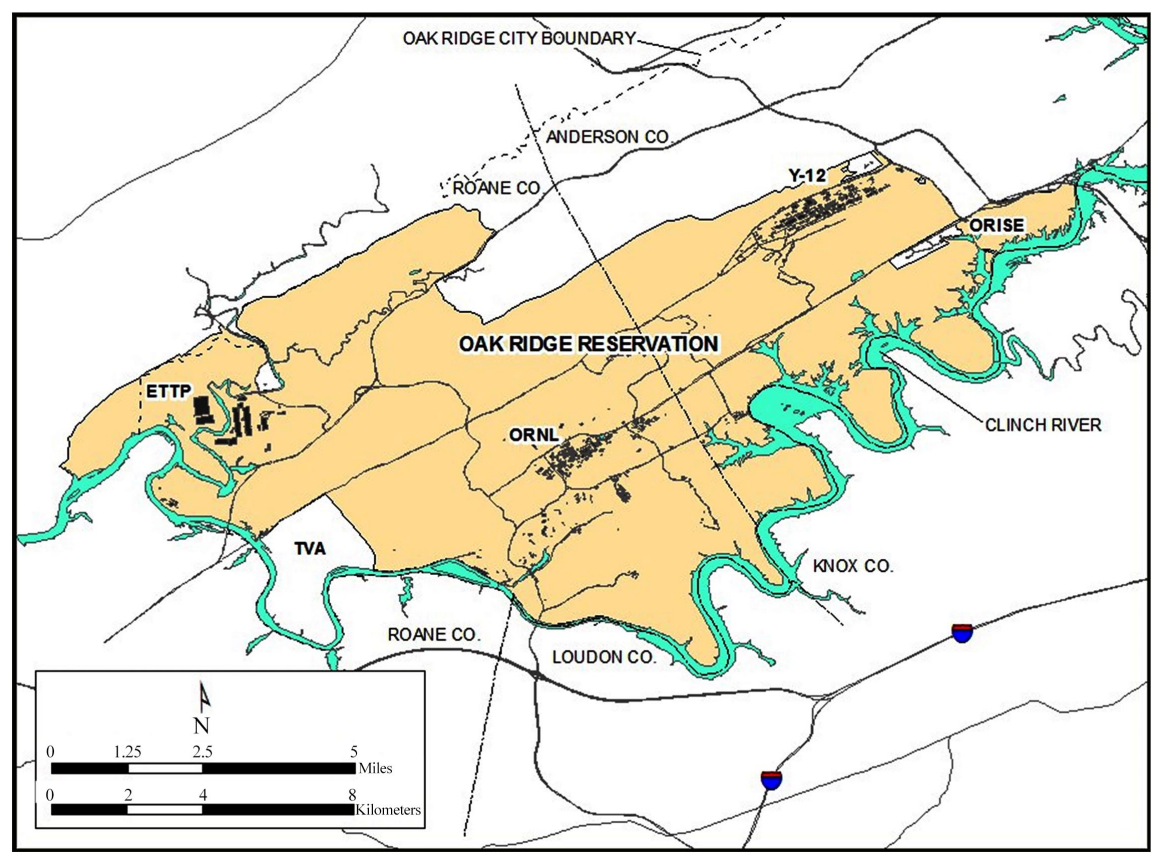

Figure 1. Map of Oak Ridge Reservation (ORR) in Anderson and Roane Co. Tennessee, 2018. 
Inventory Methods

The tree inventory method was developed collaboratively by the ORNL Natural Resources Management Program and the Department of Forestry, Wildlife and Fisheries at the University of Tennessee. Inventory methods were adopted from the i-Tree Eco protocol (i-Tree Eco Field Guide Manual v. 6.0). Attributes collected include tree species identification (genus and species), diameter at breast height $(\mathrm{DBH})(>7.62 \mathrm{~cm})$, tree conditions (good, fair, poor, critical, dead), and geographic coordinates.

Data Collection

All data were collected following the i-Tree Eco complete inventory protocol (i-Tree Eco Field Guide Manual v. 6.0). A Trimble GeoExplorer 6000 series was used to collect and store inventory data. Data collected was downloaded from the GPS unit to a desktop computer daily using the Trimble GPS Pathfinder Office version 5.81, 2015. MapInfo 15.0 created by MapInfo Corporation was used to create maps. Once all data collection was completed, it was sent to the USDA Forest Service Northern Research Station for i-Tree Eco analysis.

i-Tree Eco Analysis

$\mathrm{i}$-Tree is a suite of forest analysis and benefit assessment tools developed by the United States Department of Agriculture Forest Service

(https://www.itreetools.org/). The i-Tree suite consists of multiple analysis and benefit assessment tools that provide information on urban and community forest that can aid in forest management and advocacy. The specific software used in this study is i-Tree Eco, previously called Urban Forests Effects (UFORE) model (Nowak \& Crane, 2000). i-Tree Eco uses standardized field data from a sample inventory or complete tree inventory along with inputs of local air pollution rates and meteorological data, to quantify urban forest structure, environmental benefits and services, and the monetary value of these services (https://www.itreetools.org/; McPherson \& Simpson, 2002; Maco \& McPherson, 2003). An assessment of ORNL urban trees was conducted to quantify the same attributes. Data from 1160 trees located throughout the ORNL campus were analyzed using i-Tree Eco model version 6. The i-Tree Eco model utilized reported weather and pollution estimates from 2013 a local station in Anderson Country, TN. Importance Values (IV) as provided by the i-Tree Eco model are calculated as the sum of the percent population and percent leaf area of a given species.

\section{Statistical Analysis}

Statistical analysis for this assessment was performed using SPSS 25. A Pearson correlation coefficient was computed to determine which tree attributes were more influential on environmental effects. Tree attributes such as diameter, leaf area, and canopy size were used as independent variables to predict water interception and avoided stormwater runoff.

\section{Results and Discussion}

\section{ORNL Urban Forest Structure}


To help characterize urban forest structure we conducted a bottom-up assessment and analyzed data to provide details about species diversity, diameter distribution, and tree conditions. ORNL managed urban tree population is comprised of 1160 trees (Figure 2), with a total of 62 species, and 30 genera. The most abundant species were Acer rubrum (Red maple, 10.7\%), Cercis canadensis (Eastern redbud, 9.6\%), Quercus palustris (Pin oak, 6.3\%), Acer saccharum (Sugar maple, 6.2\%), and Juniperus virginiana (Eastern red cedar, 5.8\%) (Figure 3). Additionally, trees were categorized into diameter classes to illustrate the proportion of trees at various stages of maturity. Small trees with a diameter of $<15 \mathrm{~cm}$ constituted $34.4 \%$ of the population, whereas mid-size trees with DBH 15 and $46 \mathrm{~cm}$ accounted for $47.7 \%$, and $17.9 \%$ of the population were large/mature trees with a DBH larger than $46 \mathrm{~cm}$ (Figure 4). The mean DBH is $10.97 \mathrm{~cm}$ and the maximum DBH is $114.8 \mathrm{~cm}$ for a Quercus phellos (Pin oak) tree. Tree condition class ratings were given a numerical value good-4, fair-3, poor-2, dead-1. Condition rating was an assessment of the tree's structural integrity and health at the time of inventory. Good (4) demonstrated no apparent problem with a tree's structure, fair (3) demonstrated minor problems with tree structure, (2) major problems with a tree, critical/dead (1) extreme problems. Factors that impact structural integrity include broken or dead branches, decay, codominant stems, included bark, broken or dead roots, asymmetrical growth and potential for failure in the future. Overall tree condition ratings were categorized as $79.4 \%$ good, $15.6 \%$ fair, $2.4 \%$ poor, $1.9 \%$ critical, and $0.7 \%$ dead.

\section{Leaf Area and Importance Values}

Most of the environmental benefits are directly correlated to their leaf surface area, which is contingent on size and vegetative growth characteristics (Livesley et al., 2016). Several studies have inferred there were significant correlations between stem diameter size and crown size indicating that as stem diameter increase the crown size is greater (Livesley et al., 2016; O'Neill, 2018). Leaf area $\left(\mathrm{m}^{2}\right)$ was estimated by the i-Tree Eco model and for this study area, the canopy cover is estimated to be 4.9 ha of land area and 23.36 ha of leaf area. The species with the largest proportion of total leaf area was pin oak (11.1\%), eastern red cedar (9.2\%), and American sycamore (8.7\%). Leaf area amount for a species is a determinant of its significance or importance in an inventory. An Importance Value (IV) is calculated as the sum of the percent population and percent leaf area of a given species. Red maple (19.3), pin oak (17.4), eastern redcedar (15.0), sugar maple (13.9), eastern redbud (13.4) are the leading species with the greatest IV (Table 1; Figure 5). Red maple exceeds all other species in IV because aside from being the most abundant species within the inventory, it has the fourth-highest percent leaf area. However, in terms of DBH distribution, a third of the species (35\%) are small/young trees with an average DBH of $19.9 \mathrm{~cm}$. Thus, this species has yet to reach optimum benefit output. Pin oak is the fourth most abundant species, has the second-highest IV, and accounts for the highest proportional amount of leaf area compared to any species: 279,862 square feet of 
leaf area or $11.1 \%$ of the total leaf area. Eastern redcedar is the fifth most populous species and constitutes 226,402 square feet or $9.2 \%$ of the leaf area and has the third-highest IV. For comparison, eastern redbud is the second most abundant species, more numerous than pin oak and eastern redcedar but accounts for a total of 96,875 square feet or $3.8 \%$ of leaf area (Table 1). A high relative abundance does not suggest that this species is providing more environmental effects nor does a high importance value suggest that a particular species should be encouraged in future plantings; rather these species are currently the most abundant in the urban forest structure.

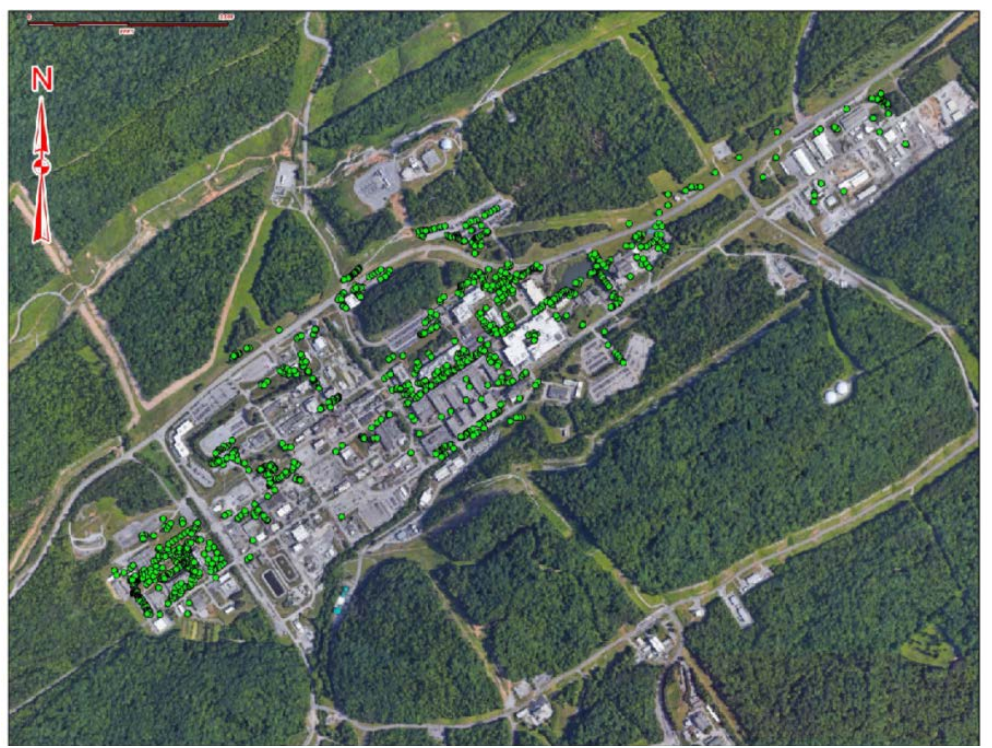

Figure 2. The distribution of urban trees (green dots) located on the main campus of Oak Ridge National Laboratory (ORNL) in Roane Co., 2018.

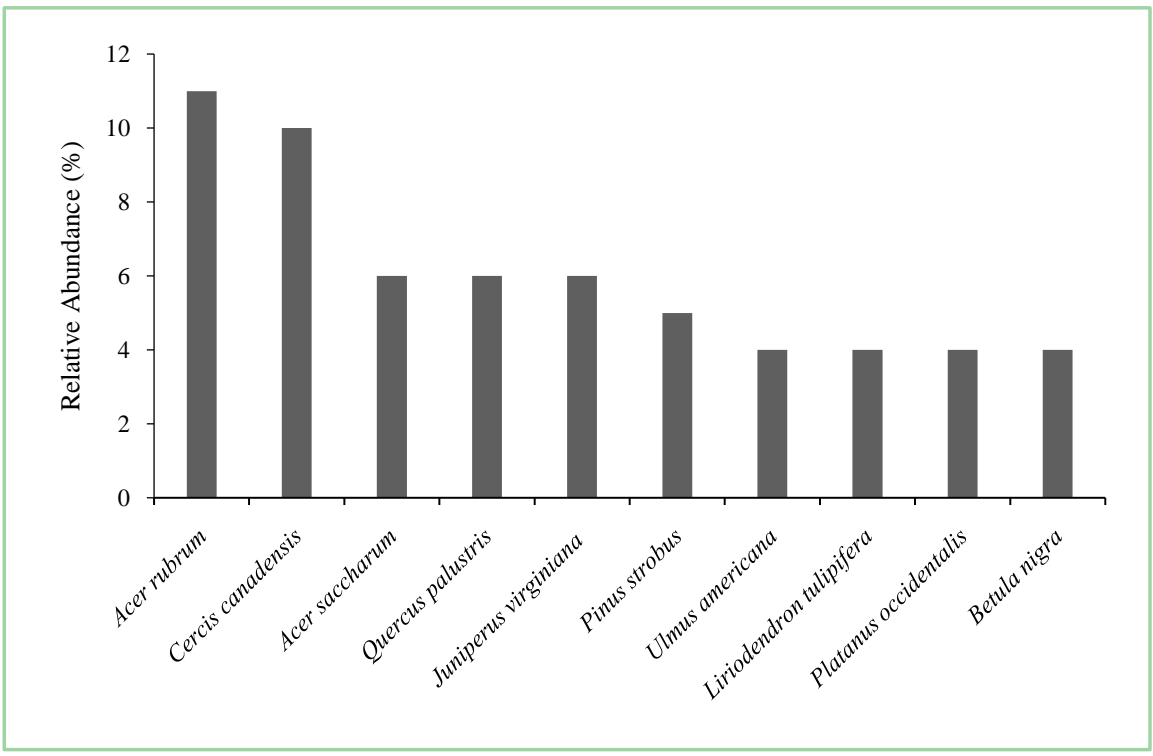

Figure 3. The most dominant tree species and their relative abundance across the ORNL campus. 


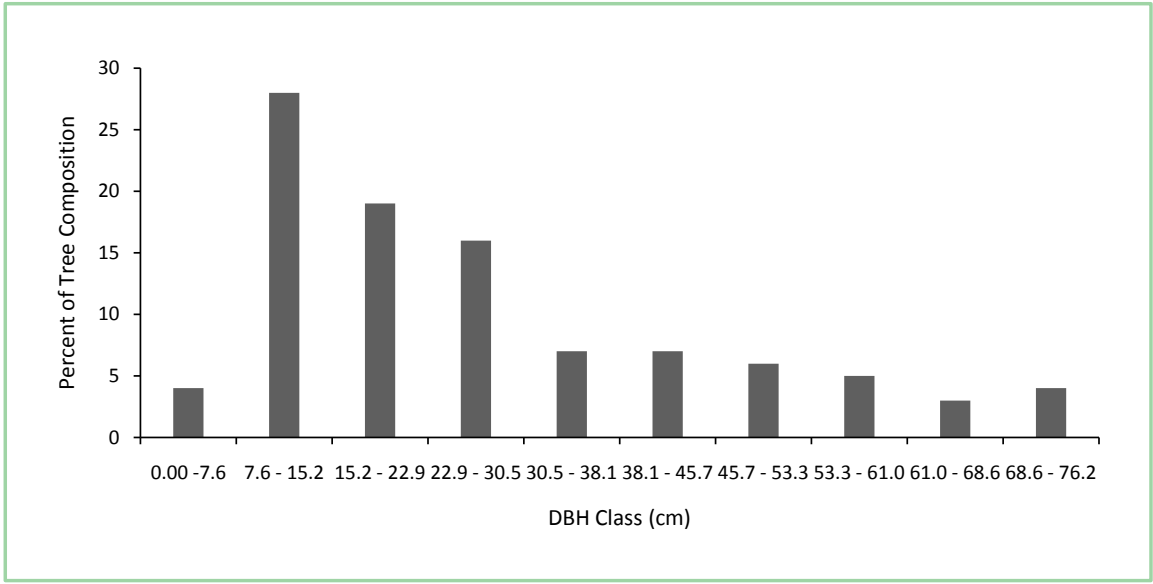

Figure 4. Percent tree population by diameter at breast height (DBH) class.

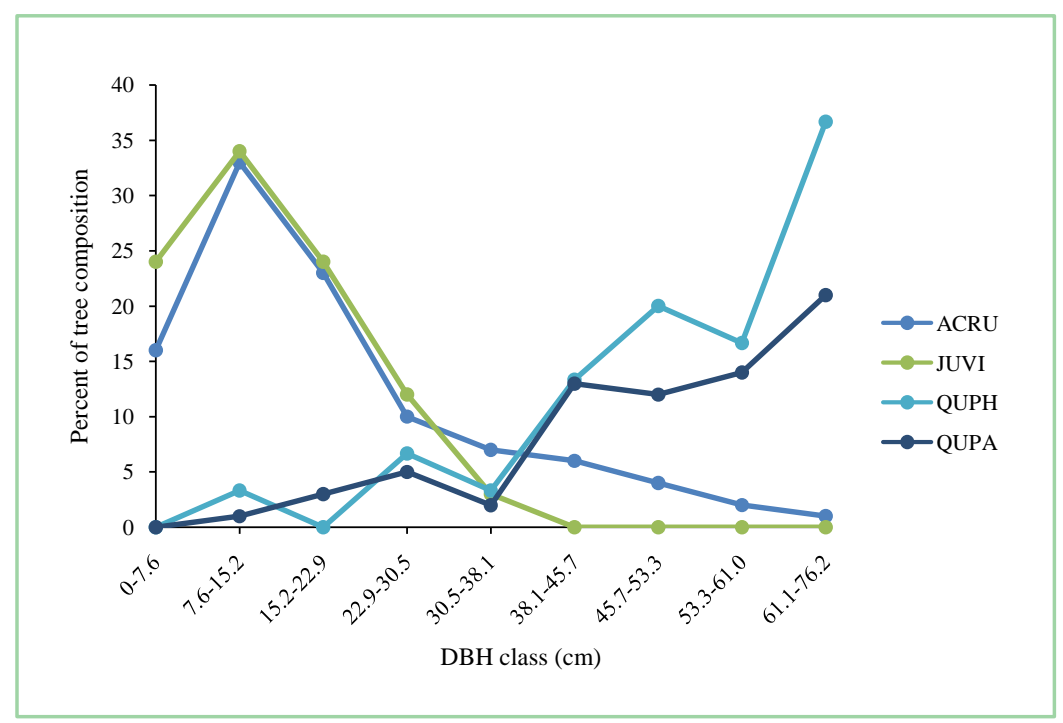

Figure 5. Distribution of diameter size in four top performing species: Acer rubrum, Juniperus virginiana, Quercus phellos, Quercus palustris populations.

Table 1. Ranking of species by importance values. Urban forest i-Tree Eco assessment.

\begin{tabular}{cccc}
\hline Species Name & Percent Population & Percent Leaf Area & IV \\
\hline Acer rubrum & 10.7 & 8.6 & 19.3 \\
Quercus palustris & 6.3 & 11.1 & 17.4 \\
Juniperus virginiana & 5.8 & 9.2 & 15 \\
Acer saccharum & 6.4 & 7.6 & 13.9 \\
Cercis canadensis & 9.6 & 3.8 & 13.4 \\
Platanus occidentalis & 3.9 & 8.7 & 12.7 \\
Pinus strobus & 5.4 & 5.8 & 11.2 \\
Liriodendron tulipifera & 4.2 & 4.1 & 8.3 \\
Ulmus americana & 4.2 & 3.9 & 8.1 \\
Quercus phellos & 2.6 & 4.5 & 7.1 \\
\hline
\end{tabular}


Structural and Functional Values

One advantage of $\mathrm{i}$-Tree Eco valuation model is its capability to provide an estimate for structural and functional value of vegetation. Structural value is the monetary value of a tree based on its physical attributes and the replacement cost for a similarly sized tree if it were removed from the landscape. Individual tree structural values are calculated using the Council of Tree, Landscape Appraisers, \& International Society of Arboriculture (2000). The CTLA formula incorporates a tree species, diameter, condition, and location information (Value $=$ Basic Tree Cost $\times$ Species Rating $\% \times$ Condition Rating $\% \times$ Location Rating\%) (Nowak et al., 2002; Gooding et al., 2000). For the trees counted in this inventory, the structural value of all species was estimated to be $\$ 2.02$ million with willow oak, eastern red cedar, pin oak, American sycamore, and eastern white pine as the leading species with the greatest structural value (Table 2). The average structural value for per willow oak was $\$ 7511$, followed by eastern red cedar at $\$ 3054$. The structural value and annual functional values are related to the quantity, size, and health of trees as illustrated in Table 2.

Carbon Storage and Sequestration

Carbon dioxide $\left(\mathrm{CO}_{2}\right)$ is among the more prominent pollutants of concern in the global climate crisis. Increased atmospheric $\mathrm{CO}_{2}$ is attributable mostly to fossil fuel and industrial processes, along with agriculture and deforestation operations worldwide (US EPA Global Greenhouse Gas Emissions Data, 2017). In 2017, the global average atmospheric $\mathrm{CO}_{2}$ was 405.0 parts per million (NOAA, 2019). Naturally, forests serve as a carbon sink by absorbing carbon during photosynthesis, storing carbon as biomass in above-and below ground structures, and producing oxygen as a by-product of photosynthesis (Bellassen \& Luyssaert, 2014). Increasing the number of trees has the potential to mitigate the accumulation of atmospheric carbon (Myneni et al., 2001). Urban areas particularly contribute to atmospheric pollution from mobile and stationary sources and continued development. Thus, urban forests perform a vital ecosystem service by sequestering and storing $\mathrm{CO}_{2}$ (Hoornweg, 2012). i-Tree Eco estimates carbon storage and gross carbon sequestration values are calculated based on the price of $\$ 143$ per ton, a value determined by i-Tree Eco. The estimated gross sequestration of all trees in this assessment was estimated to be 9.5 tons of carbon per year with an associated value of $\$ 1360$. In addition, they are estimated to store 320.6 tons of carbon amounting to $\$ 45,800$ in annual benefits. Of the species sampled, pin oaks and willow oaks accounted for approximately $35.6 \%$ of the total carbon stored and $27.1 \%$ of all sequestered carbon due to their relative abundance, large structure, and biomass capacity.

\section{Air Pollution Removal}

Air pollution effects were estimated using species characteristics, the amount of leaf biomass, and recent pollution and weather data available (base year 2013). The i-Tree Eco model estimated that trees mitigate $278 \mathrm{~kg}$ of air pollution which include Ozone $\left(\mathrm{O}_{3}\right)$, carbon monoxide $(\mathrm{CO})$, nitrogen $\left(\mathrm{NO}_{2}\right)$, and particulate matter less than 2.5 microns $\left(\mathrm{PM}_{2.5}\right)$, and sulfide oxide $\left(\mathrm{SO}_{2}\right)$ per year with a 
Table 2. Average values for characteristics of the top ten most abundant species.

\begin{tabular}{cccc}
\hline Species & \% of All trees & Avg. DBH $(\mathrm{cm})$ & Average Structural Value (\$) \\
\hline Acer rubrum & 10.7 & 19.99 & 1357 \\
Cercis canadensis & 9.6 & 14.24 & 549 \\
Acer saccharum & 6.4 & 27.35 & 1582 \\
Quercus palustris & 6.3 & 53.09 & 2789 \\
Juniperus virginiana & 5.8 & 38.36 & 3054 \\
Pinus strobus & 5.4 & 35.57 & 2265 \\
Liriodendron tulipifera & 4.2 & 17.97 & 964 \\
Ulmus americana & 4.2 & 22.23 & 967 \\
Platanus occidentalis & 3.9 & 39.81 & 2332 \\
Quercus phellos & 2.6 & 60.09 & 7511 \\
\hline
\end{tabular}

minimum value of $\$ 65.7$. Pollution removal value is calculated based on the prices of $\$ 1.6$ per $2.2 \mathrm{lbs}$. $(\mathrm{CO}), \$ 0.126$ per $2.2 \mathrm{lbs}$. $\left(\mathrm{O}_{3}\right), \$ 0.014$ per $2.2 \mathrm{lbs} .\left(\mathrm{NO}_{2}\right)$, $\$ 0.005$ per $2.2 \mathrm{lbs}$. $\left(\mathrm{SO}_{2}\right)$, $\$ 3.7$ per $2.2 \mathrm{lbs}$. $\left(\mathrm{PM}_{2.5}\right)$. While there were positive effects in relation to air pollution abatement there were also negative effects. On an annual basis, trees are estimated to emit 568.57 lbs. of volatile organic compounds (VOCs) that includes $430.6 \mathrm{lbs}$. of isoprene and $138.1 \mathrm{lbs}$. of monoterpenes. Two of the most important species (pin oak and willow oak) generated $54 \%$ of VOC emissions which have negative effects in relation to ozone formation. Increased ozone has negative effects in terms of human respiratory health.

\section{Stormwater Benefits}

Stormwater management is an area of concern among environmental managers and engineers, due to the potential of flooding following heavy rainfall. Further, it can contribute to pollution in streams, lakes, and rivers where water quality is adversely impacted. Stormwater runoff occurs when there is a significant amount of precipitation that is not captured by the tree canopy and is not absorbed by soil thus it becomes surface runoff (Hirabayashi, 2013). Urban trees and shrubs are essential in reducing runoff volumes because they capture precipitation in their canopies, while their root systems are able to filtrate and store water in the soil. All components of the tree physical structure such as leaves, branches, and bark are essential in capturing precipitation, however, only amount retained by leaves was accounted for in this analysis. Precipitation interception was estimated using rainfall totals in the base year 2013.

The total annual precipitation $(172.05 \mathrm{~cm})$ in 2013 was slightly higher than the reported precipitation totals $(156.2 \mathrm{~cm})$ in 2017 during the year of this study (https://www.ncdc.noaa.gov/cag/). Trees recorded in this inventory were estimated to intercept $4711 \mathrm{~m}^{3}$ (1,244,620 gallons) and helped to mitigate runoff by an estimated $1035 \mathrm{~m}^{3}$ (273,418 gallons) per year with an associated value of \$2440. In Table 3, Pin oak, Eastern redcedar, and American sycamore are among 
the top-performing species for stormwater benefits. The avoided runoff value is calculated by the price of $\$ 2.361 / \mathrm{m}^{3}$, a value assigned by i-Tree Eco. The i-Tree Eco model estimate results reveal that size (DBH, leaf area, and canopy size) are most important in terms of rainfall interception (Table 3).

To further investigate the association between DBH, leaf area, species abundance, and environmental effects, a stepwise regression was used to determine whether leaf area $\left(\mathrm{m}^{2}\right)$ and DBH were correlated with water interception and avoided stormwater runoff. There was a strong correlation between DBH and water interception, $r=0.88, p=\leq 0.001$. However, species abundance was moderately negatively correlated with rainfall interception $(r=-0.57)$ (Table 4). Results were similar for avoided runoff (Table 4). The number of trees did not change nor improve the model prediction of anticipated rainfall interception. This suggests that the DBH which is a predictor of leaf area and canopy size is the most important tree attribute that influences environmental effects particularly, hydrology effects (Table 3). Hence, it explains why species such a pin oak, American sycamore, and red maple are among the top-performing species in this category because of their leaf structure and expansive canopies. For comparison, eastern redbud was the second most abundant species in this inventory; however, rainfall interception was the least among this species mostly because of their small canopy size. Unfortunately, similar correlations could not be shown for other environmental effects such as air pollution reduction, because the i-Tree Eco model version 6 provided summary estimates for each species rather than estimates for individual trees. However, as described by McPherson et al., (1998), pollutant uptake is a vital benefit provided by trees as they absorb atmospheric pollutants through leaf stomata and intercept particulate matter on leaf surfaces.

Table 3. Avoided runoff values for species with the greatest overall impact on stormwater mitigation.

\begin{tabular}{ccccc}
\hline Species Name & $\begin{array}{c}\text { Number } \\
\text { of Trees }\end{array}$ & $\begin{array}{c}\text { Leaf Area } \\
(\mathbf{h a})\end{array}$ & $\begin{array}{c}\text { Water Intercepted } \\
\left(\mathbf{m}^{3} / \mathbf{y r}\right)\end{array}$ & $\begin{array}{c}\text { Avoided Runoff } \\
\left(\mathbf{m}^{3} / \mathbf{y r}\right)\end{array}$ \\
\hline Quercus palustris & 72 & 2.59 & 522.43 & 114.81 \\
Juniperus virginiana & 67 & 2.14 & 432.6 & 95.07 \\
Platanus occidentalis & 45 & 2.04 & 411.69 & 90.47 \\
Acer rubrum & 123 & 2.02 & 406.57 & 89.35 \\
Acer saccharum & 73 & 1.77 & 356.41 & 78.32 \\
Pinus strobus & 62 & 1.36 & 274.89 & 60.41 \\
Quercus phellos & 30 & 1.77 & 213.2 & 46.85 \\
Liriodendron tulipifera & 48 & 1.36 & 195.09 & 42.87 \\
Ulmus americana & 48 & 1.06 & 183.91 & 40.42 \\
Cercis canadensis & 110 & 0.97 & 180.23 & 39.61 \\
\hline
\end{tabular}


Table 4. Pearson correlation coefficient for the relation of avoided runoff, water interception, species count, leaf area, and DBH.

\begin{tabular}{|c|c|c|c|}
\hline & Avoided runoff $\left(\mathrm{m}^{3} / \mathrm{yr}\right)$ & Species count & Leaf area $\left(\mathrm{m}^{2}\right)$ DBH $(\mathrm{cm})$ \\
\hline \multicolumn{4}{|c|}{ Avoided runoff $\left(\mathrm{m}^{3} / \mathrm{yr}\right)$} \\
\hline \multirow[t]{2}{*}{ Species count } & -0.058 & & \\
\hline & $(0.025)$ & & \\
\hline \multirow[t]{2}{*}{ Leaf area $\left(\mathrm{m}^{2}\right)$} & 0.999 & -0.057 & \\
\hline & $(0.000)$ & $(0.026)$ & \\
\hline \multirow[t]{3}{*}{$\mathrm{DBH}(\mathrm{cm})$} & 0.885 & -0.108 & 0.886 \\
\hline & $(0.000)$ & $(0.000)$ & $(0.000)$ \\
\hline & Water intercepted $\left(\mathrm{m}^{3} / \mathrm{yr}\right)$ & Species count & Leaf area $\left(\mathrm{m}^{2}\right)$ DBH $(\mathrm{cm})$ \\
\hline \multicolumn{4}{|c|}{ Water intercepted $\left(\mathrm{m}^{3} / \mathrm{yr}\right)$} \\
\hline \multirow[t]{2}{*}{ Species count } & -0.057 & & \\
\hline & $(0.027)$ & & \\
\hline \multirow[t]{2}{*}{ Leaf area $\left(\mathrm{m}^{2}\right)$} & 1 & -0.057 & \\
\hline & $(0.000)$ & $(0.026)$ & \\
\hline \multirow[t]{2}{*}{$\mathrm{DBH}(\mathrm{cm})$} & 0.886 & -0.108 & 0.886 \\
\hline & $(0.000)$ & $(0.000)$ & $(0.000)$ \\
\hline
\end{tabular}

Correlation is significant $(p \leq 0.00)$ Sig. $(1$-tailed $),(n=1149)$, $p$-values are in parentheses.

\section{Conclusion}

The ORNL campus is limited in size (190.2 ha) and small in terms of urban forest composition, compared to most municipal forestry programs that have utilized the i-Tree Eco model. However, it proves to be a beneficial tool for measuring ecosystem service/environmental benefits and economic values provided by landscape vegetation. Implementing a peer-reviewed valuation model such as i-Tree Eco to estimate the structural and functional value of trees at this site helps to capture the legacy of this storied landscape, and contributes to ORNL commitment to research and environmental sustainability. i-Tree Eco model tree benefits estimates provide empirical evidence to answer questions related to costs and benefits that will help to guide tree-related priorities and substantiate ongoing tree management practices. While this assessment documents the current status of over 1100 landscape trees, the ORNL Natural Resources Management for landscape vegetation can be expanded to include unmanaged landscape, e.g. riparian areas, greenspace, other vegetative attributes, or usage of another valuation model.

Lastly, this research study sets a precedent for future urban forestry management practices at ORNL and other governmental and science institutions that have endured similar environmental challenges. The information derived in this research study can assist natural resource managers to inform policy, planning, 
and management decisions. By incorporating urban forestry management the ORNL has the opportunity to be a leader in environmental sustainability among the Department of Energy institutions.

\section{Acknowledgements}

We would like to thank The Department of Forestry, Wildlife and Fisheries, The Hebert College of Agriculture at The University of Tennessee, Knoxville, the Oak Ridge National Laboratory, and the Department of Energy for their support of this research and access to the study site.

\section{Conflicts of Interest}

The authors declare no conflicts of interest regarding the publication of this paper.

\section{References}

2018-ASER (2020). https://doeic.science.energy.gov/ASER/aser2018/01\%202018\%20ASER_Ch\%201\%20FI NAL.pdf

Andrew, C., \& Slater, D. (2014). Why Some UK Homeowners Reduce the Size of Their Front Garden Trees and the Consequences for Urban Forest Benefits as Assessed by i-Tree ECO. Arboricultural Journal: The International Journal of Urban Forestry, 36, 197-215. https://doi.org/10.1080/03071375.2014.994388

Bellassen, V., \& Luyssaert, S. (2014). Carbon Sequestration: Managing Forests in Uncertain Times. Nature News, 506, 153. https://doi.org/10.1038/506153a

Costanza, R., De Groot, R., Sutton, P., Van der Ploeg, S., Anderson, S. J., Kubiszewski, I., Turner, R. K. et al. (2014). Changes in the Global Value of Ecosystem Services. Global Environmental Change, 26, 152-158. https://doi.org/10.1016/j.gloenvcha.2014.04.002

Council of Tree, Landscape Appraisers, \& International Society of Arboriculture (2000). Guide for Plant Appraisal. Intl. Society of Arboriculture.

Data United States Climate (2018). Temperature Precipitation Sunshine Snowfall. https://www.usclimatedata.com/climate/oak-ridge/tennessee/united-states/ustn0370 https://www.energy.gov/sites/prod/files/2019/01/f58/Cleanup\%20Progress\%202018.pdf

Egoh, B., Rouget, M., Reyers, B., Knight, A. T., Cowling, R. M., van Jaarsveld, A. S., \& Welz, A. (2007). Integrating Ecosystem Services into Conservation Assessments: A Review. Ecological Economics, 63, 714-721.

https://doi.org/10.1016/j.ecolecon.2007.04.007

EPA Environmental Protection Agency (2013). Stormwater to Street Trees: Engineering Urban Forests for Stormwater Management.

Gooding, R. F., Ingram, J. B., Urban, J. R., Bloch, L. B., Steigerwaldt, W. M., Harris, R. W., \& Allen, E. N. (2000). Guide for Plant Appraisal (9th ed.). Champaign, IL: Council of Tree and Landscape Appraisers, International Society of Arboriculture.

Hirabayashi, S. (2013). i-Tree Eco Precipitation Interception Model Descriptions. New York: The Davey Tree Expert Company.

Hoornweg, D. (2012). Cities and Climate Change: An Urgent Agenda. Sustainable LowCarbon City Development in China (p. 3).

i-Tree Eco Field Guide Manual v. 6.0 (2019). 
https://www.itreetools.org/documents/275/EcoV6_UsersManual_2020_06_10_TeXiUA J.pdf

Jean-Philippe, S. (2010). The Effects of Mercury Contamination on Tree, Fungal, and Soil Composition along East Fork Poplar Creek, Anderson and Roane Counties, Tennessee. PhD Diss., Tennessee: University of Tennessee.

Jennings, T., Jean-Philippe, S. R., Willcox, A., Zobel, J., \& Simpson, T. (2016). The Influence of Attitudes and Perception of Tree Benefits on Park Management Priorities. Landscape and Urban Planning, 153, 122-128. https://doi.org/10.1016/j.landurbplan.2016.05.021

Jo, H. K., \& McPherson, G. E. (1995). Carbon Storage and Flux in Urban Residential Greenspace. Journal of Environmental Management, 45, 109-133. https://doi.org/10.1006/jema.1995.0062

Kuchelmeister, G. (1997). Urban Trees in Arid Landscapes: Multipurpose Urban Forestry for Local Needs in Developing Countries. Arid Lands Newsletter, No. 42.

Layke, C., Mapendembe, A., Brown, C. et al. (2012). Indicators from the Global and SubGlobal Millennium Ecosystem Assessments: An Analysis and Next Steps. Ecological Indicators, 17, 77-87. https://doi.org/10.1016/j.ecolind.2011.04.025

Liu, S., Costanza, R., Farber, S. et al. (2010). Valuing Ecosystem Services: Theory, Practice, and the Need for a Transdisciplinary Synthesis. Annals of the New York Academy of Sciences, 1185, 54-78. https://doi.org/10.1111/j.1749-6632.2009.05167.x

Livesley, S. J., McPherson, E. G., \& Calfapietra, C. (2016). The Urban Forest and Ecosystem Services: Impacts on Urban Water, Heat, and Pollution Cycles at the Tree, Street, and City Scale. Journal of Environmental Quality, 45, 119-124.

https://doi.org/10.2134/jeq2015.11.0567

Maco, S. E., \& McPherson, E. G. (2003). A Practical Approach to Assessing Structure, Function, and Value of Street Tree Populations in Small Communities. Journal of Arboriculture, 29, 84-97.

McDonald, R. I., Marcotullio, P. J., \& Güneralp, B. (2013). Urbanization and Global Trends in Biodiversity and Ecosystem Services. In Urbanization, Biodiversity and Ecosystem Services: Challenges and Opportunities (pp. 31-52). Dordrecht: Springer. https://doi.org/10.1007/978-94-007-7088-1_3

McPherson, E. G., \& Simpson, J. R. (2002). A Comparison of Municipal Forest Benefits and Costs in Modesto and Santa Monica, California, USA. Urban Forestry \& Urban Greening, 1, 61-74. https://doi.org/10.1078/1618-8667-00007

McPherson, E. G., Scott, K. I., \& Simpson, J. R. (1998). Estimating Cost Effectiveness of Residential Yard Trees for Improving Air Quality in Sacramento, California, Using Existing Models. Atmospheric Environment, 32, 75-84. https://doi.org/10.1016/S1352-2310(97)00180-5

Millennium Ecosystem Assessment (2005). Synthesis Report. Washington DC: Island Press. http://www.millenniumassessment.org/en/Synthesis.aspx

Myneni, R. B., Dong, J., Tucker, C. J., Kaufmann, R. K., Kauppi, P. E., Liski, J., \& Hughes, M. K. (2001). A Large Carbon Sink in the Woody Biomass of Northern Forests. Proceedings of the National Academy of Sciences, 98, 14784-14789. https://doi.org/10.1073/pnas.261555198

Nahlik, A. M., Kentula, M. E., Fennessy, M. S., \& Landers, D. H. (2012). Where Is the Consensus? A Proposed Foundation for Moving Ecosystem Service Concepts into Practice. Ecological Economics, 77, 27-35. https://doi.org/10.1016/j.ecolecon.2012.01.001 
Ning, Z. H., Chambers, R., \& Abdollahi, K. (2016). Modeling Air Pollutant Removal, Carbon Storage, and $\mathrm{CO}_{2}$ Sequestration Potential of Urban Forests in Scotlandville, Louisiana, USA. iForest, 9, 860-867. https://doi.org/10.3832/ifor1845-009

NOAA (2019). National Centers for Environmental information, Climate at a Glance: County Time Series. https://www.ncdc.noaa.gov/cag

Nowak, D. J. (1993). Historical Vegetation Change in Oakland and Its Implications for Urban Forest Management. Journal of Arboriculture, 19, 313-319.

Nowak, D. J. (1994). Air Pollution Removal by Chicago's Urban Forest. In Chicago's Urban Forest Ecosystem: Results of the Chicago Urban Forest Climate Project (pp. 63-82). Radnor, PA: US Department of Agriculture, Forest Service, Northeastern Forest Experiment Station.

Nowak, D. J., \& Crane, D. E. (2000). The Urban Forest Effects (UFORE) Model: Quantifying Urban Forest Structure and Functions. In M. Hansen, \& T. Burk (Eds.), Integrated Tools for Natural Resources Inventories in the 21st Century (pp. 714-720). Gen. Tech. Rep. NC-212, St. Paul, MN: US Dept. of Agriculture, Forest Service, North Central Forest Experiment Station.

Nowak, D. J., Crane, D. E., \& Dwyer, J. F. (2002). Compensatory Value of Urban Trees in the United States. Journal of Arboriculture, 28, 194-199.

O’Neill, S. (2018). Measuring Urban Forest Canopy Effects on Stormwater Runoff in Guelph, Ontario (Doctoral Dissertation).

Parr, P., Byrd, G., Johnston, W., \& Giffen, N. (2015). Forest Management Plan for the DOE Oak Ridge Reservation: An Interdisciplinary Approach for Managing a Heritage Resource. https://www.nrc.gov/docs/ML1802/ML18023A329.pdf

Perrings, C., Naeem, S., Ahrestani, F. S., Bunker, D. E., Burkill, P., Canziani, G., Kinzig, A. et al. (2011). Ecosystem Services, Targets, and Indicators for the Conservation and Sustainable Use of Biodiversity. Frontiers in Ecology and the Environment, 9, 512-520. https://doi.org/10.1890/100212

Perrings, C., Naeem, S., Ahrestani, F., Bunker, D. E., Burkill, P., Canziani, G., Kawabata, Z. et al. (2010). Ecosystem Services for 2020. Science, 330, 323-324. https://doi.org/10.1126/science.1196431

Reyers, B., Polasky, S., Tallis, H., Mooney, H. A., \& Larigauderie, A. (2012). Finding Common Ground for Biodiversity and Ecosystem.

Rosenfeld, A. H., Akbari, H., Romm, J. J., \& Pomerantz, M. (1998). Cool Communities: Strategies for Heat Island Mitigation and Smog Reduction. Energy and Buildings, 28, 51-62. https://doi.org/10.1016/S0378-7788(97)00063-7

Small, N., Munday, M., \& Durance, I. (2017). The Challenge of Valuing Ecosystem Services That Have No Material Benefits. Global Environmental Change, 44, 57-67. https://doi.org/10.1016/j.gloenvcha.2017.03.005

Solecki, W. D., Rosenzweig, C., Parshall, L., Pope, G., Clark, M., Cox, J., \& Wiencke, M. (2005). Mitigation of the Heat Island Effect in Urban New Jersey. Global Environmental Change Part B: Environmental Hazards, 6, 39-49. https://doi.org/10.1016/j.hazards.2004.12.002

UCOR DOE OREMP (2019). https://www.energy.gov/sites/prod/files/2019/10/f68/UCORFinalDOE-VPPReport-Jun e2019.pdf

US EPA Global Greenhouse Gas Emissions Data (2017). https://www.epa.gov/ghgemissions/global-greenhouse-gas-emissions-data

USDA Forest Service (2019). The Urban Forest of New York City. Newtown Square, PA: 
US Department of Agriculture, Forest Service, Northern Research Station. https://www.fs.fed.us/nrs/pubs/rb/rb_nrs117.pdf

USDA Soil Survey Anderson Co. (1981).

https://www.nrcs.usda.gov/Internet/FSE_MANUSCRIPTS/tennessee/TN001/0/anderso $\underline{\text { n.pdf }}$

Weber, C. (2012). Ecosystem Services Provided by Urban Vegetation: A Literature Review. In Urban Environment (pp. 119-131). Berlin: Springer.

https://doi.org/10.1007/978-94-007-7756-9_10 